\title{
ПРОГРАМУВАННЯ ПРОЦЕСУ НАВЧАННЯ ТЕХНІКИ УДАРУ НОГОЮ В СТОРОНУ «ЙОКО ГЕРІ КЕКОМІ» ХЛОПЦІВ 10 РОКІВ
}

\author{
Артур Літвін ${ }^{1 \mathrm{ABCD}}$, Світлана Марченко ${ }^{1 \mathrm{ABCD}}$ \\ ${ }^{1}$ Харківський національний педагогічний університет імені Г. С. Сковороди \\ Authors' Contribution: A - Study design; B - Data collection; C - Statistical analysis; D - Manuscript Preparation; E - Funds Collection
}

DOI: $10.17309 / \mathrm{jltm} .2021 .3 .02$

\begin{abstract}
Анотація
Мета дослідження - експериментально встановити оптимальні умови навантаження для побудови серії навчальних завдань спрямованих на засвоєння вправи «Удар ногою в сторону «йоко гері кекомі» на середньому рівні «чудан».

Матеріали і методи. У дослідженні взяли участь 32 хлопці 10 років. Діти та їхні батьки були інформовані про всі особливості дослідження і дали згоду на участь в експерименті. Для вирішення поставлених завдань були використані методи дослідження: вивчення та аналіз науково-методичної літератури, педагогічне спостереження, хронометраж навчальних завдань, педагогічний експеримент, методи математичної статистики, методи математичного планування експерименту. У процесі навчання використовувався метод алгоритмічних розпоряджень.

Результати. Перевірка однорідності дисперсій за допомогою критерію Кохрена показала, що у всіх чотирьох вибірках розбіжність між дисперсіями вважається випадковою для обраного рівня значимості 0,05. В усіх серіях виконується умова $\mathrm{Gp}<\mathrm{G} 0,05(7.4)$, досліди вважаються відтворюваними а оцінки дисперсій однорідними. Побудовані математичні моделі адекватно описують отримані дані (Fp $<$ Fкр). Признається статистична значущість моделі та надійність рівняння регресії. Дисперсійний аналіз виявив процентний вплив предикторів $\left(\mathrm{X}_{1}, \mathrm{X}_{2}\right)$ в серіях програми навчання удару ногою в сторону «йоко гері кекомі»: 1 серія - $\mathrm{X}_{1}(63,8 \%), \mathrm{X}_{2}(24,0 \%$, негативний); 2 серія - $\mathrm{X}_{1}(69,0 \%) ; 3$ серія - $\mathrm{X}_{1}(62,6 \%), \mathrm{X}_{1} \mathrm{X}_{2}(27,4 \%) ; 4$ серія - $\mathrm{X}_{1}(74,6 \%), \mathrm{X}_{2}(21,6 \%$, негативний); 5 серія - $\mathrm{X}_{1}(91,0 \%), \mathrm{X}_{1} \mathrm{X}_{2}(6,4 \%) ; 6$ серія - $\mathrm{X}_{1}(84,8 \%), \mathrm{X} 2(10,3 \%)$.

Висновки. Для раціональної організації процесу навчання удару ногою в сторону «йоко гері кекомі» на середньому рівні «чудан» хлопців 10 років за програмою алгоритмічних розпоряджень, рекомендуємо дотримуватись наступного режиму навантаження: 1 серія - 4 підходи, інтервал відпочинку 60 с; 2 серія - 4 підходи, інтервал відпочинку 60 - 120 c; 3 серія - 4 підходи, інтервал відпочинку 120 c; 4 серія - 4 підходи, інтервал відпочинку 60 с; 5 серія - 4 підходи, інтервал відпочинку 120 c; 6 серія - 4 підходи, інтервал відпочинку 120 с.

Ключові слова: хлопці, навчання, фізичні вправи, програмоване навчання, режими виконання вправ, карате, удар ногою «йоко гері кекомі».
\end{abstract}

\section{Вступ}

У тренувальній роботі з початківцями каратистами передусім слід приділяти увагу оволодінню основами техніки. У зв'язку з цим виникає питання, як починати навчання, по якій системі, щоб досягти по можливості найбільш раціонального засвоєння техніки карате. На практиці це означає необхідність оптимізації навчання і на цій основі швидке та правильне засвоєння техніки рук і ніг.

Сучасна наука та практика показують, що найкращу оптимізацію навчання та підвищення його ефективності при оволодінні основами техніки вправ забезпечує

(C) Litvin, A. \& Marchenko, S., 2021. програмування. Для цього необхідно створити навчальну програму, модель, в якій має бути точно описаний певний логічний ряд усіх дій і послідовність навчання (Błaszczyszyn, Szczęsna, Pawlyta, Marszałek, \& Karczmit, 2019; Khudolii, Iermakov, \& Bartik, 2020; Khudolii, Kapkan, Harkusha, Marchenko, \& Veremeenko, 2020). Виражаючись мовою математики, це означає створення алгоритму навчання основам базовой техніки карате (Марченко \& Коваленко, 2020; Ярошенко, 2020; Марченко \& Тараненко, 2020).

Програмоване навчання має безперечні переваги. По-перше, воно дозволяє уникнути помилок, що допускаються при індивідуальному тренерському емпіричному судженні, а також непотрібних повторень. Це дося- 
гається за допомогою строгого програмування, науково і логічно обгрунтованій моделі - програми навчання. По-друге, створюється єдина основа навчання, що, природно, покращує практику тренувальної роботи з новачками. По-третє, на основі програмованого навчання скорочується час правильного оволодіння основами техніки і вдосконалення в ній у процесі тренування. В результаті цього підвищується ефективність навчання (Lopatiev, Ivashchenko, Khudolii, Pjanylo, Chernenko, \& Yermakova, 2017; Khudolii, 2019; Khudolii, Iermakov, \& Bartik, 2020).

Morozov (2016), Arziutov, Iermakov, Bartik, Nosko, \& Cynarski, (2016) указують що математичне моделювання вважається оправданим інструментом для біолого-педагогічних досліджень та може бути доповненням до емпіричних досліджень.

Доведена ефективність використання методу моделювання в процесі навчання базовій техніці карате (Марченко \& Тараненко, 2020; Pahlevi, Fachrezzy, \&Mustafa, 2020; Марченко \& Коваленко, 2020) і розвитку рухових здібностей дітей і підлітків (Марченко, 2017; Khudolii, Ivashchenko, Iermakov, Nosko, \& Marchenko, 2019; Mapченко \& Гандимов, 2021).

Вченими доведено, що високий рівень розвитку рухових здібностей впливає на успішне виконання рухових дій і результативність у змагальній діяльності (Марченко \& Безпалько, 2020; Марченко \& Вердиш, 2021; Marchenko \& Satdyiev, 2021).

На сьогодні, як свідчать дослідження Марченко \& Коваленко (2020), Марченко \& Тараненко (2020), Szczęsna, Błaszczyszyn, \& Pawlyta (2021) та інших фахівців, не існує достатньої інформації щодо визначення алгоритму навчання основам базової техніки карате на оздоровчо-тренувальному етапі підготовки. Дана проблема дозволила сформулювати тему дослідження - «Програмування процесу навчання техніці удару ногою в сторону «йоко гері кекомі» хлопців 10 років».

Мета дослідження - експериментально встановити оптимальні умови навантаження для побудови серії навчальних завдань спрямованих на засвоєння вправи «Удар ногою в сторону «йоко гері кекомі» на середньому рівні «чудан».

\section{Матеріали і методи}

\section{Учасники дослідження}

У дослідженні взяли участь 32 хлопці 10 років. Діти та їхні батьки були інформовані про всі особливості дослідження і дали згоду на участь в експерименті.

\section{Організація дослідження}

Для вирішення поставлених завдань були використані методи дослідження: вивчення та аналіз науково-методичної літератури, педагогічне спостереження, хронометраж навчальних завдань, педагогічний експеримент, методи математичної статистики, методи математичного планування експерименту. У процесі навчання використовувався метод алгоритмічних розпоряджень.

При створенні моделі процесу навчання фізичній вправі «Удар ногою «йоко гері кекомі» ми керувались те- оретичними основами навчання, які у достатній мірі проаналізовані Платонов (2017), Khudolii, Iermakov, \& Bartik (2020). Дослідженнями Park (2003), Kang, Kim, Heo, \& Lee (2018), Szczęsna, Błaszczyszyn, \& Pawlyta (2021) про бioмеханічний аналіз техніки ударів ногами, щоб визначити просторові, часові та силові характеристики руху. Це дасть можливість оцінити достатній рівень фізичної форми і оптимально побудувати процес рухової підготовки.

Опис техніки удару. Перша фаза «фаза виносу стегна» така як і в ударі ногою «має гері» (Марченко \& Коваленко 2020). Коліно підняте до грудей, стегно майже у вертикальному положенні. При підйомі перенести центр тяжіння на опорну ногу.

Друга фаза «фаза заряду» - розворот на опорній нозі п’яткою до цілі, гомілка і стегно паралельні до підлоги, зберігати кут між стегном і гомілкою.

Третя фаза випрямлення ноги з формуванням ударної поверхні. Ударною атакуючою поверхнею $€$ «сокуто» бокова частина (ребро) стопи. Погляд спрямований у напрямку передбачуваного удару.

Четверта фаза повернення ноги у фазу «заряду».

П’ята фаза повернення ноги у «фазу виносу стегна».

Шоста фаза постановки ноги у вихідне положення «йой дачі».

Програма навчання техніці удару ногою «йоко гері кекомі» складалась із наступних послідовних серій навчальних завдань.

Перша серія - вправи для розвитку рухових здібностей.

I. Для розвитку гнучкості та рухливості у тазостегнових суглобах.

В.п.: стійка «хейсокудачі» (ноги разом), руки в сторони:

1. Мах правою в сторону, торкнутися руки ногою.

2. В.п.

3-4. Те саме другою ногою. Повторити вправу 10 разів.

Ребро стопи у положенні «сокуто», підошва опорної ноги повністю спирається на підлогу.

II. Для розвитку статичної сили м'язів ніг і спини.

В.п.: стійка на одній нозі, стоячи лівим (правим) боком до гімнастичної стінки, хват лівою (правою) рукою на рівні поясу.

1. Підняти пряму праву ногу паралельно до підлоги. Утримувати $10 \mathrm{c}$

2. В.п.

3-4. Те саме в другу сторону.

III. Для розвитку статичної рівноваги.

Виконати так само як II вправу, руки зігнуті в ліктьових суглобах, лікті опущені вниз перед собою, пальці зібрані в кулак, кулаки обох рук на рівні підборіддя.

Друга серія - вихідні і кінцеві положення.

I. Стійка «хейсоку дачі» (ноги разом).

II. Стійка ноги нарізно «йой дачі» - у цьому положенні потилиця, лопатки, сідниці, п’ятки розміщені в одній площині, ноги розведені на ширину плеч, ступні розташовані паралельно, коліна розслаблені та дещо зігнуті, руки на поясі, вага тіла розподілена рівномірно на обидві ноги (Марченко \& Коваленко 2020).

III. Широка стійка ноги нарізно «кіба дачі», відстань між стопами дві ширини плечей. Ступні паралельно та повністю спираються на підлогу. Спина пряма, перпендикулярно до підлоги. Стегна знаходяться під невеликим 
кутом до підлоги, у випадку низької стійки - паралельно до підлоги. Коліна намагатися спрямовувати в сторони. Вага тіла рівномірно розподілена на обидві ноги. Положення рук як у III вправі першої серії. Вихід у стійку «кіба дачі» може виконуватися із положення «йой дачі».

Третя серія - дії без яких неможливо виконати вправу.

I. В.п.: стійка «хейсоку дачі», руки вниз, кисті розкриті, плечі розправлені без напруження.

1. Швидко підняти ногу зігну у коліні до грудей, стегно цієї ноги майже у вертикальному положенні. При підйомі перенести центр тяжіння на опорну ногу.

2. Швидко випрямити ногу, опускаючи стопу вниз 3 формуванням ударної поверхні. Короткочасна фіксація стопи. В.п.

3-4. Те саме другою ногою. В.п.

Повторити вправу 10 разів.

Те саме можна виконувати із більш ізольованої позиції. В.п.: лежачи на лівому (правому) боці з опорою на передпліччя лівої (правої) руки.

II. В.п.: стійка на одній нозі, стоячи лівим (правим) боком до гімнастичної стінки, хват прямою лівою (правою) рукою на рівні плеча. Стегно і гомілка правої (лівої) ноги знаходяться у фазі «заряду».

1. Виконуємо хльостке розгинання ноги у колінному суглобі, зберігаючи висоту і положення стопи «сокуто» 3 фіксацією у кінцевому положенні.

2. Виконуємо швидке згинання ноги у В.п.

Виконати по 10 разів кожною ногою.

Четверта серія - навчання умінню управляти рухами:

I. В.п.: стійка на одній нозі, стоячи правим (лівим) боком до гімнастичної стінки, хват прямою правою (лівою) рукою на рівні плеча.

1. Підняти праву ногу як у I вправі третьої серії. Гомілка та стегно у вертикальній позиції.

2. Змінити положення гомілки і стегна із вертикального у горизонтальне (фаза «заряду») з одночасним поворотом лівої (опорної) стопи, зберігаючи щільність «заряду» ноги, утримувати стегно близько до тулубу. У кінцевій фазі руху стопа "сокуто» ударної ноги торкається стінки на рівні поясу, голова та п'ятка опорної ноги направлені в сторону уявного удару. Друга рука у положенні, як у III вправі першої серії.

3. Повернути праву ногу у вертикальну позицію.

4. В.п.

1-4. Те саме в другу сторону.

Повторити вправу 10 разів кожною ногою.

II. В.п.: стійка на одній нозі, стоячи правим (лівим) боком до стінки, стопа «сокуто» ударної ноги спирається на стінку на рівні поясу, положення гомілки і стегна у фазі «заряду».

Опорна нога відштовхується від підлоги вгору, друга нога відштовхується від стінки. У момент стрибка ударна нога випрямляється, у момент приземлення на опорну - збирається.

Повторити вправу 10 разів кожною ногою.

П’ята серія - окремі частини цільової вправи і підвідні вправи:

I. В.П.: стійка на одній нозі боком до перешкоди («подушка», рука партнера, резинова стрічка і т. п.), права (ліва) нога зігнута у колінному суглобі знаходиться у фазі «заряду», руки у положенні бойової стійки.
1. Виконати хльостке розгинання ноги у колінному суглобі над перешкодою, зберігаючи усі ланки тіла в одній площині, висоту і положення стопи «сокуто» $з$ фіксацією у кінцевому положенні. Ступня має бути паралельно підлозі.

2. В.п.

3-4. Те саме в другу сторону.

Повторити вправу 10 разів кожною ногою.

II. Стоячи боком до гімнастичної стінки, права (ліва) нога зігнута у колінному суглобі знаходиться у фазі «заряду», ребро стопи («сокуто») спирається у живіт партнера. Відштовхування та притягування партнера випрямляючі та згинаючи ногу, включаючи в роботу таз і стегно. Партнер чинить посильний опір. Виконати по 10 разів кожною ногою.

Шоста серія - виконання вправи в цілому:

I. Відпрацьовування техніки удару ногами із стійки «йой дачі» 3 місця в повітря. 10 разів кожною ногою.

II. Відпрацьовування техніки удару ногою, що стоїть попереду із стійки «кіба дачі» по уявній цілі з переміщенням схрестним кроком уперед. 10 разів кожною ногою.

III. Виконати другу вправу з ударом по лапам на точність і силу. 10 разів кожною ногою.

Погляд у напрямку удару. Руки у положенні бойової стійки. Дихання у всіх вправах необхідно співвідносити з темпом рухів і моментами напруги. Можливе урівноваження невеликим нахилом корпусу вбік зворотний удару, але нахилом не можна зловживати, щоб не порушити рівновагу і не ослабити силу удару.

Перехід до наступної вправи здійснювався за умови вірного виконання попередньої вправи 3 точним дотриманням усіх технічні вимог. При цьому допускались незначні помилки.

Показник навченості (Y) техніці удару ногою в сторону «йоко гері кекомі» на середньому рівні («чудан») оцінювався групою незалежних експертів у кількості трьох осіб за 10-ти бальною шкалою. Знаходилось середнє арифметичне. Одноразова незначна помилка каралась відніманням 0,1 балу. Одноразова істотна помилка відніманням 0,2 бали. При одноразовій грубій помилці віднімалось 0,3 бали.

Незначні помилки:

- Незначна втрата рівноваги.

- Опускання рук з позиції захисту голови.

- Неправильне дихання у момент виконання вправ.

- Незначна зміна траєкторії та висоти удару.

- Рухи виконуються з зайвою напругою.

Істотні помилки:

При підйомі коліна не зорієнтована ударна поверхня стопи «сокуто».

- Опорна нога повністю випрямлена або занадто зігнута.

- Стопа опорної ноги недостатньо розвернута п’яткою в напрямку удару.

- У с стійці «кіба дачі» корпус значно прогинається в поперековій області.

- Розведення або опускання рук вниз у момент виконання вправ.

- $\quad$ Погляд не спрямований у сторону удару.

Грубі помилки:

- Iстотна втрата рівноваги.

- Відсутній розворот гомілки ударної ноги в площину удару. 
- У момент фіксації удару корпус значно відхилений.

- Голова, тазостегновий суглоб і стопа ударної ноги знаходяться не в одній площині.

- Відсутнє різке і повне розгинання ударної ноги.

- У момент нанесення удару не сформована ударна поверхня стопи «сокуто».

- Пропущена одна із фаз «удару».

Для вирішення поставленої мети вивчався вплив різних варіантів виконання вправ, а саме: кількості підходів $\left(\mathrm{X}_{1}\right)$ та інтервалів відпочинку $\left(\mathrm{X}_{2}\right)$ на засвоєння техніки виконання удару ногою в сторону «йоко гері кекомі» на середньому рівні («чудан»). Хлопці 10 років були поділені на чотири групи, згідно плану експерименту. Відмінності між групами в методиці проведення занять диктувалися умовами факторного експерименту, які представлені у таблиці 1. Нижні й верхні рівні факторів були обрані на основі даних Khudolii, Kapkan, Harkusha, Marchenko, \& Veremeenko (2020), Марченко \& Коваленко (2020), Марченко \& Тараненко (2020) а також обмежувалися рамками тренувального заняття

Таблиця 1. План факторного експерименту типу $2^{2}$

\begin{tabular}{ccc}
\hline \multirow{2}{*}{$\begin{array}{c}\text { Baріанти виконання } \\
\text { вправ }\end{array}$} & \multicolumn{2}{c}{ Режими навчання } \\
\cline { 2 - 3 } & $\begin{array}{c}\text { Кількість підходів, } \\
\text { разів } \\
\left(\mathbf{X}_{\mathbf{1}}\right)\end{array}$ & $\begin{array}{c}\text { Інтервал відпо- } \\
\text { чинку, c } \\
\left(\mathbf{X}_{\mathbf{2}}\right)\end{array}$ \\
\hline 1 & $2(-)$ & $60(-)$ \\
2 & $4(+)$ & $60(-)$ \\
3 & $2(-)$ & $120(+)$ \\
4 & $4(+)$ & $120(+)$ \\
\hline
\end{tabular}

\section{Статистичний аналіз}

У роботі використані методики аналізу результатів математичного планування експерименту типу ПФЕ $2 \mathrm{k}$ (Кононюк, 2011; Khudolii \& Ivashchenko, 2014; Khudolii, Kapkan, Harkusha, Marchenko \& Veremeenko, 2020).

\section{Результати}

Результати аналізу ПФЕ $2^{2}$ наведені у таблиці 2 . Проведений експеримент показав, що регресійна залежність спостерігається протягом виконання усіх серій навчальних завдань але сила і характер впливу кожного предиктоpa $\left(\mathrm{X}_{1}, \mathrm{X}_{2}\right)$ та їх взаємодії $\left(\mathrm{X}_{1} \mathrm{X}_{2}\right)$ відіграє свою певну роль у зміні показника навченості удару ногою «йоко гері кекомі».

Перевірка однорідності дисперсій проводилася за допомогою критерію Кохрена. Результати демонструють, що у всіх чотирьох вибірках розбіжність між диспер- сіями вважається випадковою для обраного рівня значимості 0,05. Оскільки в усіх серіях виконується умова $\mathrm{Gp}<\mathrm{G} 0,05(7.4)$, то досліди вважаються відтворюваними а оцінки дисперсій однорідними. У нашому випадку признається статистична значущість моделі та надійність рівняння регресії (Fp<Fкр). Побудовані математичні моделі адекватно описують отримані дані.

Під час виконання вправ для розвитку рухових здібностей спостерігається значний позитивний вплив предиктор $\mathrm{X}_{1}$ «кількість підходів», його процентний внесок становить 63,8\%. Предиктор $\mathrm{X}_{2}$ «інтервал відпочинку» впливає негативно на 24,0\%. Збільшення параметру оптимізації потребує підвищення кількості підходів до 4 а для відпочинку достатньо 60 c.

При вивченні вихідних і кінцевих положень проявився лише позитивний вплив предиктору $\mathrm{X}_{1}$ «кількість підходів» (69,0\%). Тому для досягнення оптимального результату рекомендуємо утримувати навантаження у режимі 4 підходи а інтервал відпочинку в діапазоні 60-120 с.

Рівняння регресії, яке характеризує вплив факторів у серії «Дії без яких неможливо виконати вправу» демонструє найбільший позитивний вплив предиктора $\mathrm{X}$ «кількість підходів» (62,6\%), та ефект взаємодії предикторів $\left(\mathrm{X}_{1} \mathrm{X}_{2}\right)(27,4 \%)$. Для підвищення значення цільової характеристики можемо рекомендувати тренувальний режим: 4 підходи з інтервалами відпочинку 120 с. У процесі навчання умінню управляти рухами на значення цільової характеристики позитивно впливає предиктор $\mathrm{X}_{1}$ «кількість підходів» (74,6\%). Інший характер впливу має предиктор $\mathrm{X}_{2}$ «інтервал відпочинку» $(21,6 \%)$. Навчальні завдання цієї серії краще виконувати у режимі 4 підходи з інтервалами відпочинку 60 c.

Необхідно звернути увагу на досить високу силу впливу предиктора $\mathrm{X}_{1}$ «кількість підходів» $(91,0 \%)$ у досягненні цільової характеристики у серії «Окремі частини цільової вправи і підвідні вправи». Взаємодія предикторів $\left(\mathrm{X}_{1} \mathrm{X}_{2}\right)$ здійснює позитивний вплив на оцінку виконання техніки вправ на 6,4\%. Оптимальні комбінації навантаження у даній серії 4 підходи з інтервалами відпочинку $120 \mathrm{c}$.

Ефективність навчання у серії «Виконання вправи в цілому» пояснюється позитивним впливом двох предикторів - $\mathrm{X}_{1}$ «кількість підходів» $(84,8 \%)$ і $\mathrm{X}_{2}$ «інтервал відпочинку» (10,3\%). Варіант виконання вправ повинен бути з наступним навантаженням: 4 підходи з інтервалами відпочинку 120 c.

У першій і четвертій серіях спостерігаються негативні знаки коефіцієнтів регресії предиктору $\mathrm{X}_{2}$. У даному випадку величина цільової характеристики зростає якщо значення предиктору убуває.

Таблиця 2. Результати аналізу ПФЕ $2^{2}$. Хлопці 10 років

\begin{tabular}{|c|c|c|c|c|}
\hline \multirow{2}{*}{ Серії навчальних занять } & \multirow{2}{*}{ Рівняння регресії для кодованих змінних } & \multicolumn{3}{|c|}{ Відсотковий вплив на показник навченост } \\
\hline & & $\mathrm{X}_{1}$ & $\mathrm{X}_{2}$ & $\mathrm{X}_{1} \mathrm{X}_{2}$ \\
\hline 1 & $\mathrm{Y}=8,643+0,377 \mathrm{X}_{1}-0,231 \mathrm{X}_{2}$ & 63,8 & 24,0 & 12,2 \\
\hline 2 & $\mathrm{Y}=9,135+0,261 \mathrm{X}_{1}$ & 69,0 & 18,1 & 12,9 \\
\hline 3 & $Y=8,768+0,312 X_{1}+0,207 X_{1} X_{2}$ & 62,6 & 10,0 & 27,4 \\
\hline 4 & $\mathrm{Y}=8,977+0,271 \mathrm{X}_{1}-0,146 \mathrm{X}_{2}$ & 74,6 & 21,6 & 3,8 \\
\hline 5 & $\mathrm{Y}=8,3+1,049 \mathrm{X}_{1}+0,278 \mathrm{X}_{1} \mathrm{X}_{2}$ & 91,0 & 2,6 & 6,4 \\
\hline 6 & $\mathrm{Y}=8,844+0,637 \mathrm{X}_{1}+0,222 \mathrm{X}_{2}$ & 84,8 & 10,3 & 4,9 \\
\hline
\end{tabular}


У другій, третій, п'ятій, та шостій серіях позитивні знаки коефіцієнтів говорять про те, що зі збільшенням значення предиктору зростає величина цільової характеристики.

У третій та п'ятій серіях навчальних завдань взаємодія двох предикторів значима і має позитивний знак. Це свідчить про те, що одночасне збільшення їх значень призведе до збільшення цільової характеристики (без урахування лінійних ефектів).

У п'ятій та шостій серіях навчальних завдань високі значення коефіцієнтів при предикторі $\mathrm{X}_{1}$ указують на значну силу впливу «кількості підходів».

Таким чином, проведений факторний експеримент типу $2^{2}$ виявив оптимальні режими навчання техніці удару ногою в сторону «йоко гері кекомі» у хлопців 10 рокі. Ефективними моделями тренувальної дії $€$ :

1 серія - 4 підходи, інтервал відпочинку 60 ;;

2 серія - 4 підходи, інтервал відпочинку 60-120 c;

3 серія - 4 підходи, інтервал відпочинку 120 c;

4 серія - 4 підходи, інтервал відпочинку 60 c;

5 серія - 4 підходи, інтервал відпочинку 120 c;

6 серія - 4 підходи, інтервал відпочинку 120 c.

\section{Дискусія}

Дослідження припускало, що ступінь засвоєння техніки удару ногою в сторону «йоко гері кекомі» на середньому рівні «чудан» пов’язано з поділом навчального матеріалу на покрокові навчальні процедури та від різних умов навантаження під час виконання вправ.

Отримані дані доповнюють інформацію про використання факторів, що впливають на ефективність розвитку рухових навичок (Hiley, Schmid, \& Yeadon, 2019; Khudolii, Kapkan, Harkusha, Marchenko, \& Veremeenko, 2020; Ivashchenko, Iermakov, \& Khudolii, 2021).

Отримана у ході експерименту інформація підтверджує доцільність використання методу моделювання для удосконалення процесу навчання та можливість створювати на його основі різноманітні засоби навчання техніці у одноборствах (Pahlevi, Fachrezzy, \& Mustafa, 2020; Mapченко \& Коваленко, 2020; Марченко \& Тараненко, 2020).

Розширено уявлення про необхідність урахування кінетичних і кінематичних факторів (Bo-Seob, Hyo-Taek, \& Yong-Jae, 2015), оптимальну взаємодію різних ланок тіла (Gavagan \& Sayers, 2017; Hariri \& Sadeghi, 2018; Błaszczyszyn, Szczęsna, Pawlyta, Marszałek \& Karczmit, 2019), правильну

\section{Література}

Błaszczyszyn, M., Szczęsna, A., Pawlyta, M., Marszałek, M. Karczmit, D. (2019). Kinematic Analysis of Mae-Geri Kicks in Beginner and Advanced Kyokushin Karate Athletes. Int. J. Environ. Res. Public Health, 16(17), 3155. https://doi.org/10.3390/ijerph16173155

Khudolii, O., Iermakov, S., \& Bartik, P. (2020). Didactics: methodological basis of motor learning in children and adolescents. Journal of Learning Theory and Methodology, 1(1). https://doi.org/10.17309/jltm.2020.1.01

Khudolii, O., Kapkan, O., Harkusha, S., Marchenko, S., \& Veremeenko, V. (2020). Motor Skills Development: Optimization of Teaching Boys Aged 15 Press Headstand роботу м'язової системи (Tae-Won, Hye-Soo, \& ByeongHo, 2020; Aryadi, Sudirman, Ridwan, Suharto, Rahmat, \& Assayid, 2021), оптимізацію умов навчання ударам ногами (Марченко \& Коваленко, 2020; Марченко \& Тараненко, 2020; Marchenko, Jagiello, Iermakov, Ivashchenko, \& Khudolii, 2021), для придбання учнями умінь і навички досконалого володіння технікою. Так як зміна траєкторії руху, порушення структури удару та неправильний розподіл сил може привести до додаткового навантаження на суглоби, викликати ушкодження м'яких тканин (Kashefi, Daneshjoo, \& Mousavi Sadati, 2020).

Отримані нові дані. Розроблено поетапну програму навчання базовому елементу в кіокушинкай карате удару ногою в сторону «йоко гері кекомі» на середньому рівні «чудан» у відповідності з теорією побудови рухів, теорією адаптації організму до фізичних навантажень, теорією функціональних систем та інших (Бернштейн, 1966; Анохин, 1980 та інші). Побудовано регресійні моделі навчання для кожної серії навчальних вправ аргументами яких $є$ статистично значимі предиктори.

Використання розробленої методики дозволяє розподілити засоби підготовки і визначити цільові показники яких необхідно досягти учням у процесі навчання. Дозволить скоротити термін засвоєння технічних дій в карате.

\section{Висновки}

Для раціональної організації процесу навчання удару ногою в сторону «йоко гері кекомі» на середньому рівні «чудан» хлопців 10 років за програмою алгоритмічних розпоряджень, рекомендуємо дотримуватись наступного режиму навантаження:

1 серія - 4 підходи, інтервал відпочинку 60 c;

2 серія - 4 підходи, інтервал відпочинку 60 - 120 c;

3 серія - 4 підходи, інтервал відпочинку 120 с;

4 серія - 4 підходи, інтервал відпочинку 60 с;

5 серія - 4 підходи, інтервал відпочинку 120 с;

6 серія - 4 підходи, інтервал відпочинку 120 с.

Отримані розробки можуть використовуватись на уроках фізичної культури, у позакласній роботі та тренувальній діяльності на спортивно-оздоровчому і початковому етапах

\section{Конфлікт інтересів}

Автори заявляють про відсутність конфлікту інтересів.

\section{References}

Błaszczyszyn, M., Szczęsna, A., Pawlyta, M., Marszałek, M., Karczmit, D. (2019). Kinematic Analysis of Mae-Geri Kicks in Beginner and Advanced Kyokushin Karate Athletes. Int. J. Environ. Res. Public Health, 16(17), 3155. https://doi.org/10.3390/ijerph16173155

Khudolii, O., Iermakov, S., \& Bartik, P. (2020). Didactics: methodological basis of motor learning in children and adolescents. Journal of Learning Theory and Methodology, 1(1). https://doi.org/10.17309/jltm.2020.1.01

Khudolii, O., Kapkan, O., Harkusha, S., Marchenko, S., \& Veremeenko, V. (2020). Motor Skills Development: Optimization of Teaching Boys Aged 15 Press Headstand 
and Handstand. Teoriâ ta Metodika Fizičnogo Vihovannâ, 20(1), 42-48. https://doi.org/10.17309/tmfv.2020.1.06

Марченко, С., \& Коваленко, К. (2020). Оптимізація режиму навчання техніки прямого удару ногою «має гері» в кіокушинкай карате хлопців 10 років. Журнал теоріі та методології навчання, 1(1), 33-39. https://doi.org/10.17309/jltm.2020.1.05

Ярошенко, Д.В. (2020). Структура тренировочного занятия на этапе начальной подготовки юных каратистов. Физическая культура. Спорт. Туризм. Двигательная рекреация, 5(1), 92-102.

https://doi.org/10.24411/2500-0365-2020-15114

Марченко, С., \& Тараненко, О. (2020). Керування ефективністю навчання техніки колового удару ногою «маваші гері» у кіокушинкай карате хлопців 10 років. Теорія та методика фізичного виховання, 20(4), 262268. https://doi.org/10.17309/tmfv.2020.4.10

Lopatiev, A., Ivashchenko, O., Khudolii, O., Pjanylo, Y., Chernenko, S., \& Yermakova, T. (2017). Systemic approach and mathematical modeling in physical education and sports. Journal of Physical Education and Sport, 17(1), 146155. https://doi.org/10.7752/jpes.2017.s1023

Khudolii, O. (2019). Research Program: Modeling of Young Gymnasts' Training Process. Teoriâ ta Metodika Fizičnogo Vihovannâ, 19(4), 168-178. https://doi.org/10.17309/tmfv.2019.4.02

Morozov, A. (2016). Modelling biological evolution: Linking mathematical theories with empirical realities. Journal of Theoretical Biology, 405, 1-4. http://doi.org/10.1016/j.jtbi.2016.07.007

Arziutov, G., Iermakov, S., Bartik, P., Nosko, M., Cynarski, \& Wojciech J. (2016). The use of didactic laws in the teaching of the physical elements involved in judo techniques. Ido Movement for Culture, 16(4), 21-30. http://doi.org/10.14589/ido.16.4.4

Pahlevi, F., Fachrezzy, F., Mustafa (2020). Model latihan teknik tendangan momtong yeop chagi pada atlet taekwondo universitas negeri jakarta. Jurnal Pendidikan Jasmani dan Adaptif, (3), 8-15. https://doi.org/10.21009/jpja.v3i01.15569

Марченко, C.I. (2017). Моделювання процесу розвитку спритності у хлопчиків 2-4 класів засобами рухливих ігор. Теорія та методика бізичного виховання, 17(2), 98-104. https://doi.org/10.17309/tmfv.2017.2.1194

Khudolii, O., Ivashchenko, O., Iermakov, S., Nosko, Y., \& Marchenko, S. (2019). Strength Abilities: Estimation of Immediate Training Effect of Strength Loads in Girls Aged 7 Years. Teoria ta Metodika Fizičnogo Vihovanna, 19(2), 98-104. https://doi.org/10.17309/tmfv.2019.2.06

Марченко, С., \& Гандимов, Б. (2021). Розвиток силових здібностей ігровими засобами з елементами одноборств на спортивно-оздоровчому етапі у дівчат 10 років. Журнал теорії та методології навчання, 2(2), 68-74. https://doi.org/10.17309/jltm.2021.2.03

Марченко, С., \& Безпалько, Д. (2020). Контроль і оцінка координаційних здібностей хлопчиків 7 років на етапі початкової підготовки в кіокушинкай карате. Журнал теорії та методології навчання, 1(2), 82-88. https://doi.org/10.17309/jltm.2020.2.06

Марченко, С., \& Вердиш, Я. (2021). Оцінка надійності та інформативності показників координаційної підготовленості хлопчиків 8 років. Журнал теорії ma методології навчання, 2(1), 21-28. https://doi.org/10.17309/jltm.2021.1.03 and Handstand. Teoriâ ta Metodika Fizičnogo Vihovannâ, 20(1), 42-48. https://doi.org/10.17309/tmfv.2020.1.06

Marchenko, S., \& Kovalenko, K. (2020). Optimization of Teaching Boys Aged 10 Mae-Geri (Front Kick) Technique in Kyokushin Karate. Journal of Learning Theory and Methodology, 1(1), 33-39.

https://doi.org/10.17309/jltm.2020.1.05

Iaroshenko, D.V. (2020). Struktura trenirovochnogo zaniatiia na etape nachalnoi podgotovki iunykh karatistov. Fizicheskaia kultura. Sport. Turizm. Dvigatelnaia rekreatciia, 5(1), 92-102.

https://doi.org/10.24411/2500-0365-2020-15114

Marchenko, S., \& Taranenko, O. (2020). Managing the Effectiveness of Teaching Boys Aged 10 Mawashi-Geri (Roundhouse Kick) Technique in Kyokushin Karate. Teorîa ta Metodika Fizičnogo Vihovannâ, 20(4), 262-268. https://doi.org/10.17309/tmfv.2020.4.10

Lopatiev, A., Ivashchenko, O., Khudolii, O., Pjanylo, Y., Chernenko, S., \& Yermakova, T. (2017). Systemic approach and mathematical modeling in physical education and sports. Journal of Physical Education and Sport, 17(1), 146155. https://doi.org/10.7752/jpes.2017.s1023

Khudolii, O. (2019). Research Program: Modeling of Young Gymnasts' Training Process. Teoriâ ta Metodika Fizičnogo Vihovannâ, 19(4), 168-178. https://doi.org/10.17309/tmfv.2019.4.02

Morozov, A. (2016). Modelling biological evolution: Linking mathematical theories with empirical realities. Journal of Theoretical Biology, 405, 1-4. http://doi.org/10.1016/j.jtbi.2016.07.007

Arziutov, G., Iermakov, S., Bartik, P., Nosko, M., Cynarski, \& Wojciech J. (2016). The use of didactic laws in the teaching of the physical elements involved in judo techniques. Ido Movement for Culture, 16(4), 21-30. http://doi.org/10.14589/ido.16.4.4

Pahlevi, F., Fachrezzy, F., Mustafa (2020). Model latihan teknik tendangan momtong yeop chagi pada atlet taekwondo universitas negeri jakarta. Jurnal Pendidikan Jasmani dan Adaptif, (3), 8-15. https://doi.org/10.21009/jpja.v3i01.15569

Marchenko, S. (2017). Modeling Dexterity Development in 2nd-4th-grade Boys by Means of Active Games. Teoriâ ta Metodika Fizičnogo Vihovannâ, 17(2), 98-104. https://doi.org/10.17309/tmfv.2017.2.1194

Khudolii, O., Ivashchenko, O., Iermakov, S., Nosko, Y., \& Marchenko, S. (2019). Strength Abilities: Estimation of Immediate Training Effect of Strength Loads in Girls Aged 7 Years. Teoria ta Metodika Fizičnogo Vihovanna, 19(2), 98-104. https://doi.org/10.17309/tmfv.2019.2.06

Marchenko, S., \& Handymov, B (2021). Development of Strength Abilities Using Play Techniques with Elements of Martial Arts at the Sports and Recreational Stage in 10-Year-Old Girls. Journal of Learning Theory and Methodology, 2(2), 68-74. https://doi.org/10.17309/jltm.2021.2.03

Marchenko, S., \& Bezpalko, D. (2020). Control and Assessment of 7-Year-Old Boys' Coordination Abilities at the Initial Training Stage in Kyokushin Karate. Journal of Learning Theory and Methodology, 1(2), 82-88. https://doi.org/10.17309/jltm.2020.2.06

Marchenko, S., \& Verdysh, Ya. (2021). Assessment of Reliability and Informativeness of Coordination Fitness Indicators of 8-Year-Old Boys. Journal of Learning Theory and Methodology, 2(1), 21-28. https://doi.org/10.17309/jltm.2021.1.03 
Marchenko, S., \& Satdyiev, B. (2021). Effectiveness of Using Active Games for Strength Development in 10-Year-Old Boys at the Initial Training Stage in Kyokushin Karate. Teoriâ ta Metodika Fizičnogo Vihovannâ, 21(1), 84-89. https://doi.org/10.17309/tmfv.2021.1.11

Szczęsna, A., Błaszczyszyn, M., \& Pawlyta, M. (2021). Optical motion capture dataset of selected techniques in beginner and advanced Kyokushin karate athletes. Scientific Data, 8(13), 1-12. https://doi.org/10.1038/s41597-021-00801-5

Платонов, В. (2017). Теории адаптации и функциональных систем в развитии системы знаний в области подготовки спортсменов. Наука в олимпийском cnopme, 1, 29-47. https://www.researchgate.net/ publication/320234321

Park, K.D. (2003). A Kinematical Analysis of Side Kick Motion in Taekwondo. Korean Journal of Sport Biomechanics, 13(2), 49-63. https://doi.org/10.5103/KJSB.2003.13.2.049

Kang, D. W., Kim, H. R., Heo, W. S. \& Lee, K. K. (2018). Biomechanical Comparative Analysis of the Dominant and the Non-Dominant According of rhe Type of Yeopchagi. Taekwondo Journal of Kikkiwon, 9(1), 197-217. https://doi.org/10.24881/tjk.2018.9.1.197

Кононюк, А.Е. (2011). Основы научных исследований (Общая теория эксперимента): Монография : в 4 кн. Кн. 2. Киев : КНТ, 452. (in Ukrainian)

Худолій, О.М., \& Іващенко, О.В. (2014). Моделювання процесу навчання та розвитку рухових здібностей у дітей $i$ підітків: Монограбія. Харків: ОВС, 320. (in Ukrainian).

Hiley, M.J., Schmid, N., \& Yeadon, M.R. (2019). How do technique and coordination change during learning of a wholebody task: Application to the upstart in gymnastics. Journal of Sports Sciences, 37(20), 2374-2380. https://doi.org/10.1080/02640414.2019.1634413

Ivashchenko, O., Iermakov, S., \& Khudolii, O. (2021). Modeling: ratio between means of teaching and motor training in junior school physical education classes. Pedagogy of Physical Culture and Sports, 25(3), 194-201. https://doi.org/10.15561/26649837.2021.0308

Bo-Seob, H., Hyo-Taek, L., \& Yong-Jae, K. (2015). Kinetic Analysis of the Apkkoaseogi Yeopchagi in Taekwondo. Journal of Sport and Leisure Studies, 61, 625-637. https://doi.org/10.51979/KSSLS.2015.08.61.625

Gavagan, C.J., \& Sayers, M.G.L. (2017). A biomechanical analysis of the roundhouse kicking technique of expert practitioners: A comparison between the martial arts disciplines of Muay Thai, Karate, and Taekwondo. PLoS ONE, 12(8): e0182645.

https://doi.org/10.1371/journal.pone.0182645

Hariri, S., \& Sadeghi, H. (2018). Biomechanical Analysis of Mawashi-Geri Technique in Karate: Review Article. J Sport Stud Hlth., 1(4):e84349. https://doi.org/10.5812/intjssh.84349

Tae-Won, K., Hye-Soo, C., Byeong-Ho, Y. (2020). The Comparative Analysis on Electromyography between Skilled and Non-skilled Side kickers in the Front Cross Stance Position of Taekwondo. Korean Journal of Sports Science, 29(4), 1195-1204. https://doi.org/10.35159/kjss.2020.08.29.4.1195

Aryadi, D., Sudirman, R., Ridwan, M., Suharto, T.H., Rahmat, A., and Assayid, W.S. (2021). The Relationship Between Limb Muscle Power and Balance With "Yeop Chagi” Kick Technique on Taekwondo on The Members of Gunung Karang Taekwondo Club (GKTC) 1995, Pandeglang Regency. Journal of Physics: Conference Series 1764. https://doi.org/10.1088/1742-6596/1764/1/012141
Marchenko, S., \& Satdyiev, B. (2021). Effectiveness of Using Active Games for Strength Development in 10-Year-Old Boys at the Initial Training Stage in Kyokushin Karate. Teoriâ ta Metodika Fizičnogo Vihovannâ, 21(1), 84-89. https://doi.org/10.17309/tmfv.2021.1.11

Szczęsna, A., Błaszczyszyn, M., \& Pawlyta, M. (2021). Optical motion capture dataset of selected techniques in beginner and advanced Kyokushin karate athletes. Scientific Data, 8(13), 1-12. https://doi.org/10.1038/s41597-021-00801-5

Platonov, V. (2017). Teorii adaptatcii i funktcionalnykh sistem v razvitii sistemy znanii v oblasti podgotovki sportsmenov. Nauka v olimpiiskom sporte, 1, 29-47. https://www. researchgate.net/publication/320234321

Park, K.D. (2003). A Kinematical Analysis of Side Kick Motion in Taekwondo. Korean Journal of Sport Biomechanics, 13(2), 49-63. https://doi.org/10.5103/KJSB.2003.13.2.049

Kang, D. W., Kim, H. R., Heo, W. S. \& Lee, K. K. (2018). Biomechanical Comparative Analysis of the Dominant and the Non-Dominant According of rhe Type of Yeopchagi. Taekwondo Journal of Kikkiwon, 9(1), 197-217. https://doi.org/10.24881/tjk.2018.9.1.197

Kononiuk, A.E. (2011). Osnovy nauchnykh issledovanii (Obshchaia teoriia eksperimenta): Monografiia : v $4 \mathrm{kn}$. Kn. 2. Kiev : KHT, 452. (in Russian)

Khudolii, O.M., \& Ivashchenko, O.V. (2014). Modeliuvannia protsesu navchannia ta rozvytku rukhovykh zdibnostei u ditei i pidlitkiv: Monohrafiia. Kharkiv: OVS, 320. (in Ukrainian).

Hiley, M.J., Schmid, N., \& Yeadon, M.R. (2019). How do technique and coordination change during learning of a wholebody task: Application to the upstart in gymnastics. Journal of Sports Sciences, 37(20), 2374-2380. https://doi.org/10.1080/02640414.2019.1634413

Ivashchenko, O., Iermakov, S., \& Khudolii, O. (2021) Modeling: ratio between means of teaching and motor training in junior school physical education classes. Pedagogy of Physical Culture and Sports, 25(3), 194-201. https://doi.org/10.15561/26649837.2021.0308

Bo-Seob, H., Hyo-Taek, L., \& Yong-Jae, K. (2015). Kinetic Analysis of the Apkkoaseogi Yeopchagi in Taekwondo. Journal of Sport and Leisure Studies, 61, 625-637. https://doi.org/10.51979/KSSLS.2015.08.61.625

Gavagan, C.J., \& Sayers, M.G.L. (2017). A biomechanical analysis of the roundhouse kicking technique of expert practitioners: A comparison between the martial arts disciplines of Muay Thai, Karate, and Taekwondo. PLoS ONE, 12(8): e0182645.

https://doi.org/10.1371/journal.pone.0182645

Hariri, S., \& Sadeghi, H. (2018). Biomechanical Analysis of Mawashi-Geri Technique in Karate: Review Article. J Sport Stud Hlth., 1(4):e84349. https://doi.org/10.5812/intjssh.84349

Tae-Won, K., Hye-Soo, C., Byeong-Ho, Y. (2020). The Comparative Analysis on Electromyography between Skilled and Non-skilled Side kickers in the Front Cross Stance Position of Taekwondo. Korean Journal of Sports Science, 29(4), 1195-1204. https://doi.org/10.35159/kjss.2020.08.29.4.1195

Aryadi, D., Sudirman, R., Ridwan, M., Suharto, T.H., Rahmat, A., and Assayid, W.S. (2021). The Relationship Between Limb Muscle Power and Balance With "Yeop Chagi” Kick Technique on Taekwondo on The Members of Gunung Karang Taekwondo Club (GKTC) 1995, Pandeglang Regency. Journal of Physics: Conference Series 1764. https://doi.org/10.1088/1742-6596/1764/1/012141 
Marchenko, S., Jagiello, W., Iermakov, S., Ivashchenko, O., \& Khudolii, O. (2021). Pattern recognition: modes of teaching boys aged 10 mae-geri (front kick) technique in kyokushin karate. ARCH BUDO, 17, 253-261.

Kashefi, T., Daneshjoo, A., Mousavi Sadati, S.K. (2020). The Effect of a Course of Up-cholugi and Yup-chagi Exercises on the Kinematic Indices of the Knee and the Incidence of Bow-leggedness (Genu Varum) in Professional Taekwondo Practitioners (Persian). Journal of Sport Biomechanics, 6(4), 214-225.

https://doi.org/10.32598/biomechanics.6.3.1

Бернштейн, Н.А. (1966). Очерки по физиологии движений и физиологии активности. М.: Медицина, 350.

Анохин, П.К. (1975). Очерки по физиологии функииональных систем. М.: Медицина, 402.
Marchenko, S., Jagiello, W., Iermakov, S., Ivashchenko, O., \& Khudolii, O. (2021). Pattern recognition: modes of teaching boys aged 10 mae-geri (front kick) technique in kyokushin karate. ARCH BUDO, 17, 253-261.

Kashefi, T., Daneshjoo, A., Mousavi Sadati, S.K. (2020). The Effect of a Course of Up-cholugi and Yup-chagi Exercises on the Kinematic Indices of the Knee and the Incidence of Bow-leggedness (Genu Varum) in Professional Taekwondo Practitioners (Persian). Journal of Sport Biomechanics, 6(4), 214-225. https://doi.org/10.32598/biomechanics.6.3.1

Bernshtein, H.A. (1966). Ocherki po fiziologii dvizhenii $i$ fiziologii aktivnosti. M.: Meditcina, 350.

Anokhin, P.K. (1975). Ocherki po fiziologii funktcionalnykh sistem. M.: Meditcina, 402.

\title{
PROGRAMMING THE PROCESS OF TEACHING BOYS AGED 10 YOKO GERY KEKOMI (SIDE KICK)
}

\section{Artur Litvin, Svitlana Marchenko ${ }^{1 \mathrm{ABCD}}$}

\author{
${ }^{1}$ H. S. Skovoroda Kharkiv National Pedagogical University
}

Authors' Contribution: A - Study design; B - Data collection; C - Statistical analysis; D - Manuscript Preparation; E - Funds Collection Report. Article: 9 p., 2 tabl., 35 sources.

The purpose of the study is to experimentally establish the optimal load conditions for the construction of a series of educational tasks aimed at mastering the exercise "Kick in the direction of" yoko geri kekomi "at the average level of" weird ".

Materials and methods. The study involved 32 boys aged 10 years. The children and their parents were informed about all the features of the study and agreed to participate in the experiment. Research methods were used to solve the tasks: study and analysis of scientific and methodological literature, pedagogical observation, timing of educational tasks, pedagogical experiment, methods of mathematical statistics, methods of mathematical planning of the experiment. The method of algorithmic instructions was used in the learning process.

Results. Checking the homogeneity of the variances using the Cochren test showed that in all four samples the discrepancy between the variances is considered random for the selected significance level of 0.05 . In all series the condition Gr $<\mathrm{G} 0.05$ (7.4) is fulfilled, the experiments are considered reproducible and the estimates of variances are homogeneous. The constructed mathematical models adequately describe the obtained data (Fp < Fкр). The statistical significance of the model and the reliability of the regression equation are recognized. Analysis of variance revealed the percentage effect of predictors $\left(X_{1}, X_{2}\right)$ in the series of the program of kicking in the direction of "yoko geri kekomi": 1 series - $\mathrm{X}_{1}(63.8 \%), \mathrm{X}_{2}(24.0 \%$, negative); Series $2-\mathrm{X}_{1}(69.0 \%) ; 3$ series $-\mathrm{X}_{1}(62.6 \%), \mathrm{X}_{1} \mathrm{X}_{2}(27.4 \%) ; 4$ series $-\mathrm{X}_{1}$ $(74.6 \%), \mathrm{X}_{2}\left(21.6 \%\right.$, negative); 5 series $-\mathrm{X}_{1}(91.0 \%), \mathrm{X}_{1} \mathrm{X}_{2}(6.4 \%)$ 6 series $-\mathrm{X}_{1}(84.8 \%), \mathrm{X}_{2}(10.3 \%)$.

Conclusions. For the rational organization of the process of learning to kick "yoko geri kekomi" at the average level of "weird" boys 10 years old according to the program of algorithmic instructions, we recommend the following load regime: 1 series - 4 approaches, rest interval 60 s; 2 series -4 approaches, rest interval $60-120 \mathrm{~s} ; 3$ series -4 approaches, rest interval $120 \mathrm{~s} ; 4$ series -4 approaches, rest interval $60 \mathrm{~s}$; 5 series -4 approaches, rest interval $120 \mathrm{~s} ; 6$ series -4 approaches, rest interval $120 \mathrm{~s}$.

Keywords: boys, training, physical exercises, programmed training, modes of performance of exercises, karate, kick «yoko geri kekomi».

\section{Information about the authors:}

Litvin Artur: arturlitvin1999@gmail.com; https://orcid.org/0000-0003-2207-8717; H. S. Skovoroda Kharkiv National Pedagogical University, Department of Theory and Methodology of Physical Education, Alchevskykh St, 29, Kharkiv, 61002, Ukraine.

Marchenko Svitlana: sport-svet1968@ukr.net; https://orcid.org/0000-0002-1013-9511; H. S. Skovoroda Kharkiv National Pedagogical University, Department of Theory and Methodology of Physical Education, Alchevskykh St, 29, Kharkiv, 61002, Ukraine.

Cite this article as: Litvin, A., \& Marchenko, S. (2021). Programming the process of teaching boys aged 10 yoko gery kekomi (side kick). Journal of Learning Theory and Methodology, 2(3), 111-118. https://doi.org/10.17309/jltm.2021.3.02

Received: 25.09.2021. Accepted: 05.10.2021. Published: 30.10.2021

This work is licensed under a Creative Commons Attribution 4.0 International License (http://creativecommons.org/licenses/by/4.0). 